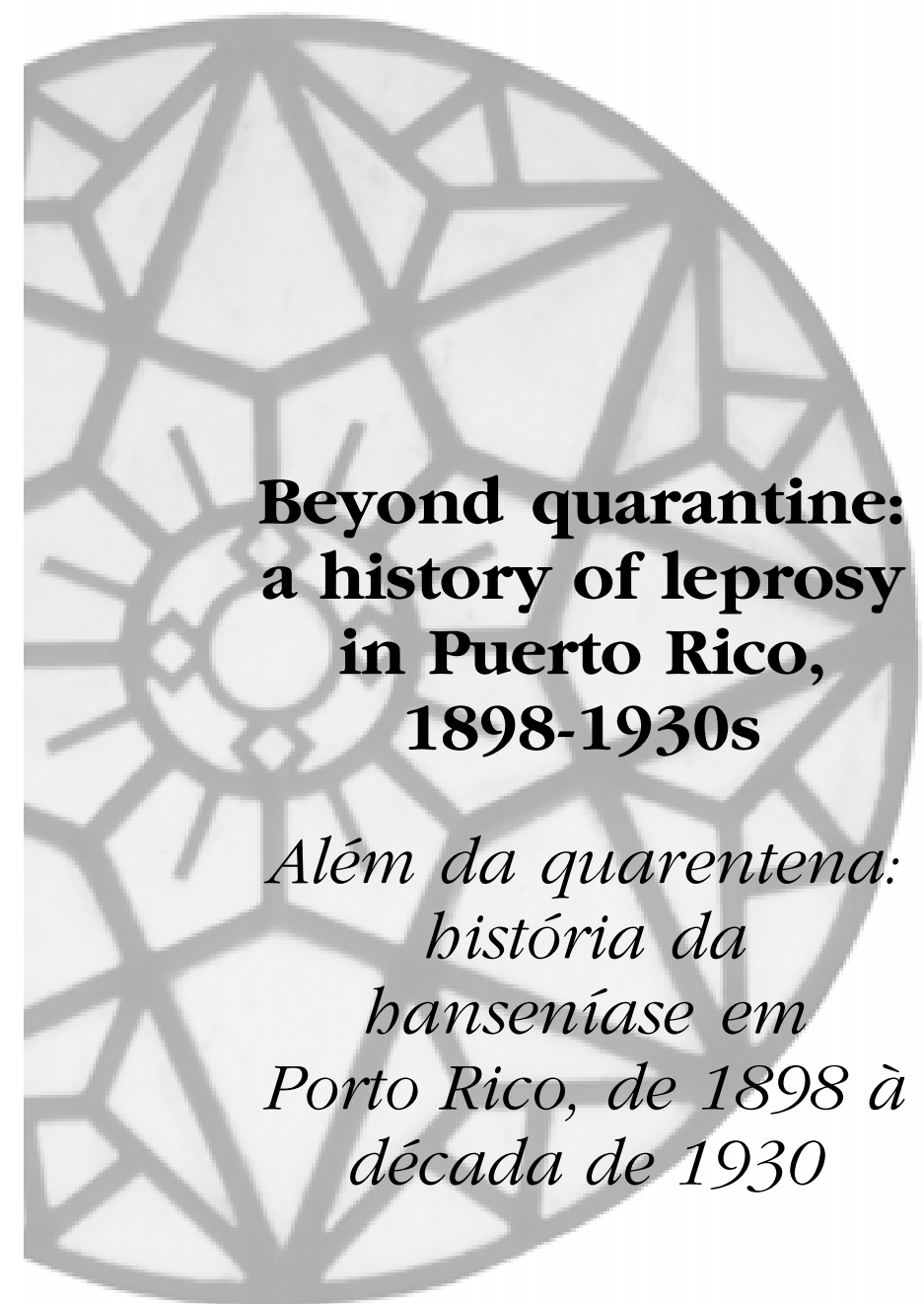

Julie H. Levison

M.D. candidate, Harvard Medical School MPhil, Economic and Social History,

Oxford University, England

400 Brookline Ave.

Boston, MA 02215 U.S.A

Julie_Levison@student.hms.harvard.edu
LEVISON, J. H.: 'Beyond quarantine: a history of leprosy in Puerto Rico, 1898-1930s'. História, Ciências, Saúde - Manguinhos, vol. 10 (supplement 1): 225-45, 2003.

From biblical times to the modern period, leprosy has been a disease associated with stigma. This mark of disgrace, physically present in the sufferers' sores and disfigured limbs, and embodied in the identity of a 'leper', has cast leprosy into the shadows of society. This paper draws on primary sources, written in Spanish, to reconstruct the social history of leprosy in Puerto Rico when the United States annexed this island in 1898. The public health policies that developed over the period of 1898 to the 1930s were unique to Puerto Rico because of the interplay between political events, scientific developments and popular concerns. Puerto Rico was influenced by the United States' priorities for public health, and the leprosy control policies that developed were superimposed on vestiges of the colonial Spanish public health system. During the United States' initial occupation, extreme segregation sacrificed the individual rights and liberties of these patients for the benefit of society. The lives of these leprosy sufferers were irrevocably changed as a result. KEYWORDS: leprosy, Puerto Rico, United States, social history, colonial medicine.

LEVISON, J. H.: 'Além da quarentena: história da hanseníase em Porto Rico, de 1898 à década de 1930.

História, Ciências, Saúde-Manguinbos, vol. 10 (suplemento 1): 225-45, 2003.

Dos tempos bíblicos ao periodo moderno, a hanseniase tem sido associada a estigmas. Essa marca de desonra, fisicamente presente nas feridas e nos membros desfigurados do 'leproso', e incorporada a sua identidade, lancou a doença aos rincões mais obscuros da sociedade. Opresente artigo usa fontes primárias, escritas em espanbol, para reconstruir a bistória social da lepra em Porto Rico a partir de 1898, quando os Estados Unidos anexaram a ilha a seu território. As políticas de saúde pública desenvolvidas em Porto Rico até a década de 1930 foram específicas, devido a uma combinação de fatores políticos, científicose sociais. Opaís sofreu a influência das prioridades sanitárias dos Estados Unidose desenvolveu suas políticas de controle da lepra sobre os vestígios do sistema de saúde da Espanha colonial. No início da ocupação norteamericana, extrema segregação agrediu a liberdade e os direitos individuais dos pacientes, em nome da proteção à sociedade. Como resultado, as vidas desses hansenianos foram irrevogavelmente transformadas.

PALAVRAS-CHAVE: hanseniase, Porto Rico, Estados Unidos, história social, medicina colonial. 
1 All quotes from Spanish-titled sources used in this paper were translated by the author.
When the boat disappeared from the small wharf, the grateful sick remained waving from the rocks with their handkerchiefs and their hats, asking to God that all of society realize that they exist, in that crag apart. ${ }^{1}$

(A. Rodríguez Vera, 1920)
2 The identification of leprosy patients as 'lepers' signifies that the identity of leprosy defines the constitution of the sufferer. A result of the Fifth International Leprosy Congress in 1948 was the agreement that the term 'leper' was offensive because of the stigma associated with its use. In this essay, the term 'leprosy patient' or 'leprosy sufferer' is used instead of 'leper' unless the term 'leper' is relevant to the discussion.
$I^{1}$ $\mathrm{n}$ this passage, Rev. Rodríguez Vera, pastor to the leprosy sufferers isolated on Isla de Cabras, poignantly addresses three distressing aspects of the treatment of leprosy: removal of the patient from the family and community, the patients' fear they would be not only invisible but forgotten, and the dependency between the sufferer and his caregiver. For Rev. Rodrigúez Vera, leprosy was not simply a disease presented by an unfortunate victim. Leprosy and being a 'leper' were synonymous. ${ }^{2}$ Their disease defined their identity. Patients suffering from leprosy have lived in exile, banished to islands and enclosed institutions that remove leprosy sufferers from sight.

From biblical times to the modern period leprosy has been a disease associated with stigma. This mark of disgrace, physically present in the sufferers' sores and disfigured limbs, and embodied in the identity of a 'leper', has cast leprosy sufferers into the shadows of society. The stigma and segregation of leprosy sufferers has an ancient past. In the bible it is written that a 'leper' is unclean, that a 'leper' should live in isolation, and that his dwelling shall be outside the camp (American Bible Society, 1989). Leprosy is still a model of disease where patients suffer the stigma of having not only corporal but also spiritual and moral corruption. This study of leprosy examines those historical influences, from 1898 to 1930, that shaped public health policies in Puerto Rico to favour the segregation of leprosy sufferers and those factors that caused these policies to develop during this period.

Leprosy was among a number of diseases that challenged public health authorities in Puerto Rico at the beginning of the United States' occupation of the island. When science could not provide hope for a treatment for leprosy, public health measures in Puerto Rico relied on traditional measures of quarantine. However, at the beginning of the twentieth century, isolation measures for leprosy in Puerto Rico were distinct from control practices used for other diseases at the time. While separating the diseased from the healthy population, isolation of leprosy sufferers also had social consequences. It usurped individual liberty, disturbed relations between the individual and society, altered the bond between family members, distanced the citizen from social benefits and challenged laws and social codes. Underlying disregard for the leprosy sufferers particularly by the political legislators determined the fate of the leprosy sufferers when science could not. 
There were three important factors that reinvigorated old concerns about the perceived highly contagious aspect of leprosy and influenced how public health authorities created and deployed models for leprosy control. First, while debates persisted among physicians about the mode of leprosy's transmission, the bacterial identification of leprosy in 1873 elevated the theory that leprosy was a highly contagious disease. The detectable presence of leprosy the bacillus facilitated increased case detection even if those cases had existed previously but had gone undetected. Second, in 1889, the death of Father Damien, who devoted his life to the care of destitute leprosy patients at the leprosarium of Hawaii, indicated that even the most virtuous could become a 'leper'. Third, heightened international concern for leprosy, particularly for the spread of leprosy from foreign territories and populations, influenced the guidelines for leprosy control established by the First International Leprosy Congress, in 1897. Their recommendations privileged a form of isolation more severe than the traditional nineteenth century notion of quarantine for contagious diseases. Without an available cure for leprosy, the First International Congress determined that every 'leper' was a danger to society and permitted the involuntary and indefinite separation of the leprosy sufferer from society.

When the United States became a colonial power in the SpanishAmerican War and gained control of Puerto Rico, the military government first channeled its resources into the surveillance and mitigation of disease threats to their military troops stationed in Puerto Rico. At the end of the nineteenth and early twentieth centuries, the priority the United States placed on leprosy control and the alarm across the Western world about the threat of leprosy in colonial areas influenced the initial reaction to exclude leprosy sufferers from the Puerto Rican society. Segregation, backed by international leprosy guidelines, was the most efficient means for the United States to remove leprosy sufferers from visible sight while not burdening public resources. Once invisible from society, the leprosy sufferer was soon forgotten. It was clear in the early years of leprosy control that the purpose of segregation at Isla de Cabras was the elimination of leprosy from Puerto Rico by eliminating the human reservoir of infection. The disease and the diseased were inextricably linked. After almost twenty years of increasing resistance to the idea of abject island segregation of the leprosy sufferers, relocation became a reality. The Puerto Rico Legislative Assembly passed an act in 1919 to establish a new leprosarium. This was a result of pressure from the medical community in Puerto Rico, the agitation within Protestant missions who had been faithful supporters of the United States colonial occupation of Puerto Rico, the increasing awareness of the potential medical therapy in chaulmoogra oil and the recent passage of a bill in Congress to build a United States National Leprosarium on the mainland. The Puerto Rico Legislative 
Assembly could no longer justify to the public segregation of the leprosy patients at Isla de Cabras and public health policy modified as a result. The Third International Congress on Leprosy in 1923 supported a more humane form of isolation for leprosy cases. With this new model as an example, Puerto Rico identified a forty-acre site for a new leprosarium at Trujillo Alto. In 1926, 43 patients left behind the island in hope of a new beginning at the leprosy institution.

\section{Leprosy: the historical context}

For the historian of medicine, the end of the nineteenth century and early twentieth century presents a unique set of questions for the study of leprosy and disease management. A traditional historiographical approach would rely on sources from colonial officials to narrate the story of disease control in colonial territories. Over the past twenty years, with the development of postcolonial histories of medicine, historians of medicine have become suspicious of the collusion between medicine and imperial campaigns (Anderson, 1998, p. 523; Arnold, 1988). Recent histories of the United States as a colonial empire show that research priorities in Puerto Rico did not necessarily correspond to the public health needs of local communities but rather was driven by American military and economic interests (Farley, 1991). There have been several histories of leprosy in colonial settings that unearth the connection of colonial control and disease management through the case study of leprosy (Gussow, 1989; p. 210; Illife, 1987). With the integration of oral histories into histories of medicine, several studies on leprosy have emphasized the value in local patient voices in contributing to the study of the relationship between the disease, the patient, the doctor, and the larger social context.

The history of leprosy in Puerto Rico has been understudied by historians. Most of what is known on leprosy and the leprosy patients in Puerto Rico comes from several epidemiological studies between 1926 and 1951. While epidemiological data provides information on the distribution of leprosy based on sex, age, and geographical location, it does not provide a context from which to understand the patient's experience living with leprosy (Doull et al., 1941; Malaret, 1951; Botet Vázquez et al. 1980; Almodóvar et al., 1990; Sanchez et al., printing forthcoming). In the end of the 1960s, the Department of Dermatology of the University of Puerto Rico assumed responsibility for the medical care of the leprosy patients at Trujillo Alto. There was an effort to educate the local Puerto Rican population about leprosy and its history. Puerto Rican newspapers addressed the stigma associated with leprosy and recognized the severity of segregation that Puerto Rican leprosy sufferers experienced ('2.400 Puerto Ricans are suffering', 1973; 'Restaurarán ruinas Leprocomio de Palo Seco', 1964). An 
interesting study that does investigate the history of leprosy among a general history of quarantine in Puerto Rico during the nineteenth century unfortunately ends in 1900 when Isla de Cabras becomes the leprosarium for Puerto Rico (Vázquez Ortiz, 1992).

This study draws on a rich body of primary sources, written in Spanish, to reconstruct the social history of leprosy as a disease and as a public health challenge in Puerto Rico from 1898, when the United States annexed the island, until the 1930s, after the Department of Health relocated leprosy patients to an insular leprosarium. Government reports, medical textbooks, scientific articles, and unpublished personal correspondences and papers establish the constellation of factors that influenced the policy and practice of leprosy control in Puerto Rico. The writings of leprosy patients themselves form the foundation for the patient narrative. Letters from patients and their caregivers were published in the journal of the Protestant Evangelical Union, Puerto Rico Evangélico. This unusual source provides a balance of voices from the political policy-makers, health planners and the patients themselves.

\section{Leprosy control in Puerto Rico}

The local and informal leprosy control measures by the Spanish authorities in the eighteenth and nineteenth centuries provide a notion of the extent of change in the management and control of leprosy under the United States. Historians have traced the existence of leprosy in Puerto Rico to the arrival of slaves from Africa in the eighteenth century. Fray Iñigo Abad y Lasierra wrote a historical survey of Puerto Rico in 1788 where he described the presence of leprous inhabitants on the island (Malaret, 1951, p.15). However, it is difficult to know whether all of these patients he identified had leprosy as it is clinically described today. Records from the Spanish Provincial Board of Health, established in 1768, indicate that this governmental agency inconsistently controlled leprosy. A report from the town council of San Juan indicates that for the first time, in 1812, the city provided a small monetary allowance for a leprosy sufferer with the intention of removing the indigent sick from the streets (Vázquez Ortiz, 1992). There were several attempts to control leprosy but local municipalities maintained the responsibility of the leprosy sufferers. In 1876, the town council of San Juan ultimately built a hospital at Isla de Cabras on the west side of the Bay of San Juan, and leprosy was among the contagious diseases that were held at this facility that served the purpose of a maritime quarantine station (Hostos, 1966, p. 472).

Within the city of San Juan at the end of the nineteenth century, living conditions were poor and increasingly unsanitary and overcrowded. In 1880, the council of San Juan built a shelter in the back of the city jail 
to house vagrant leprosy sufferers called Puerta de Tierra, a one-story building constructed of wood on the south side of the city jail, with room for six patients. The isolation was incomplete since the detention center was surrounded by a slum of small wooden huts (United States Public Health Service, 1904, p. 115). Furthermore, compulsory isolation for leprosy sufferers in Puerta de Tierra was not regularly enforced. Since the jail housed leprosy sufferers who roamed the streets, those patients who officials isolated were almost completely drawn from the indigent classes. The leprosy patients housed at Puerta de Tierra before the United States' arrival became a target for management, as the United States public health authorities carried with them from the mainland a heightened and punitive stance on leprosy control.

\section{8: The United States arrives}

The end of the nineteenth century was not only a period of massive migration into the United States, but also a time of outward colonial expansion for the United States and for other great Western powers. In the year 1898, the United States, once a former colony of Britain, became a colonial power by annexing Puerto Rico in the Spanish American War. The Treaty of Paris declared that the United States Congress could determine the civil rights and political conditions of the territories ceded by Spain. By October 1898, the United States Congress implemented a military government and military provision of health care for the inhabitants of Puerto Rico.

With the remnants of a Spanish health care structure, the United States had to create a new health care structure. And the military model for public health organization initially shaped the provision of health care in Puerto Rico. In 1898, the Surgeon General George Sternberg called for creation of committees to monitor those diseases that would threaten troops and hinder the progression of the American mission to democratize and restructure the territories. As the United States Public Health Service surveyed the status of leprosy in the United States, it was also able to do it in its territories. Military authorities conducted a search in Puerto Rico and identified a total of sixty leprosy cases out of a population of 950,000, and eleven leprosy sufferers were identified and isolated in San Juan at Puerta de Tierra (Puerto Rico, Governor, 1901, p. 4). Although leprosy was not among the diseases of highest prevalence in Puerto Rico, it was particularly a public health issue because there were leprosy sufferers living as vagabonds and mendicants in San Juan. Leprosy sufferers roaming the streets were visually unappealing to the capital city of this new United States territory and a hindrance to improving sanitation in San Juan.

With the creation of the Superior Board of Health by Governor Henry in 1899, the inadequate condition of leprosy facilities at Puerta de Tierra were apparent. At the time of the inspection, the leprosy 
${ }^{3}$ For a full description of the Spanish quarantine buildings on Isla de Cabras, see Vázquez Ortiz (1992). isolation facility in the rear of the city jail at Puerta de Tierra housed two patients. The facility's condition was poor, worsened by San Ciriaco, the hurricane of 8 August 1899, that destroyed the facility and rendered those detained for leprosy without shelter. The United States Marine Hospital Service relocated the leprosy sufferers to the basement of the city jail, as a temporary structure until the health officers could select another site. With the initial disease surveillance completed and the state of leprosy assessed, the campaign towards leprosy isolation began. Governor Henry called for military funds to commission the construction of an insular 'leper colony' to finally control leprosy in Puerto Rico.

Isla de Cabras contained the structural elements of an isolation point. The island was one mile in length and less than an eighth of a mile in width. ${ }^{3}$ There was a natural barrier of rocks and rough surf that made the northern and southern side facing San Juan unapproachable by boat. Most of the island's buildings were made of brick and cement and included a disinfection facility, a large wooden warehouse, a dispensary and a manager's lodge. The main isolation ward was divided into two bays. At one end of the room was a small kitchen equipped for a charcoal fire and cement laundry basins. A cemetery and wooden picket fence partitioned this quarantine facility from the rest of the island. While Isla de Cabras contained elements of a detention camp and isolation hospital, upon the United States' arrival to Puerto Rico, Governor C. H. Lavinder found the conditions 'criminally poor' (Puerto Rico, Governor, 1902, p. 278).

The exigencies brought by the hurricane, the concern over the spread of yellow fever through increased trade relations, and the homeless leprosy sufferers, shaped the public health agenda. The Governor explained why leprosy sufferers were highlighted for intervention: "In regard to the lepers, whose disease renders them a menace to public health, not only compassion for their suffering, but also security for the sound inhabitants, requires their isolation and consequent support and relief" (Puerto Rico, Governor, 1901, p. 53).

The Governor's report indicates leprosy sufferers were a threat to community health, their segregation was for the common good, and as a "dependent class" there was no consideration of their rehabilitation. Despite difficulties in collaborating with Puerto Rican civilian authorities, the United States military health officers remained committed to addressing the number of visible leprosy sufferers in San Juan and creating a system of sanitation that would fulfil the sophisticated health expectations of the United States.

Since Isla de Cabras was unsuitable for maritime quarantine, sanitation officials located another island, Miraflores, at the upper end of the harbor at San Juan. The maritime quarantine station would be used particularly for the control of incoming vessels that contained yellow fever cases. Compared to Isla de Cabras, Miraflores was four times the size; approachable by ship; contained a defunct factory that 
could be converted into accommodations; and instead of a cistern, contained a spring that could pump water throughout the island. Sanitation officials advised Governor Davis that the refurbishment of the buildings and water system could convert Miraflores into a satisfactory maritime quarantine, and 'then Cabras Island, at a very little expense, could be fitted up for the isolation of the leper colony' (Marine Hospital Service, 1899, p. 1670). The officials called this plan the 'island exchange', the purpose of Isla de Cabras transplanted to Miraflores. While the United States and international quarantine recommendations indicated that both leprosy and yellow fever were worthy of quarantine, the example of the site selection for the leprosarium in Puerto Rico shows that quarantine of yellow fever clearly took priority in resources (ibid).

Acting Governor William Hunt created a committee for the purpose of establishing a leper colony, and in August 1900 a committee reviewed the suitability of Isla de Cabras as a 'leper colony'. A letter in August 1899, from Governor Henry to Charles G. Post, President of the Board of Public Works, explained Henry's expectations for the colony:

My idea is that the hospital should be constructed as economically as possible and that the committee should make such recommendations as shall seem prudent and safe in the premises, for the purpose of carrying out the contemplated removal (Archivo General de Puerto Rico, 1900, Leg. 80, Exp. 2, Caja 661).

After agreement on the extent of repairs needed and the financing of these projects on Isla de Cabras, on 21 August 1900, the Commissioner of the Interior, W. H. Elliot, announced plans to remove the detained leprosy sufferers in San Juan to Isla de Cabras. By 17 October 1900, the patients at Puerta de Tierra were moved to the erected leprosarium at Isla de Cabras. This concern for expediency and economy influenced the treatment of the leprosy patients at Isla de Cabras for the following 26 years.

\section{Isla de Cabras: the 'Leper Colony'}

Segregation was the efficient means to control leprosy in Puerto Rico, based on the contemporary international guidelines, scientific knowledge, and general lack of regard for leprosy sufferers. The Puerto Rican health authorities referred to the leprosy patients detained at Isla de Cabras as 'inmates' rather than patients quarantined for rehabilitation. While a preliminary search for leprosy patients on the island occurred in 1899, in 1901 the Board of Charities who presided over the care of the leprosy patients, endeavored to find the other sixty individuals with leprosy 'at large' on the island. The director of the Board of Charities justified this attention to their isolation by explaining that it was best to 'colonize' these afflicted people at a location 
"where they can be properly cared for without danger to the other inhabitants" (Puerto Rico, Governor, 1901, pp. 52-3).

In the first decade of the twentieth century, the facility of Isla de Cabras spiraled into an uninhabitable state. The Director of Health, Dr. Quevado Baéz, recommended to the Department of the Interior that improved living conditions at the leprosarium were necessary not only to fulfill the standards that the Board of Health set for general sanitation on the island but also because the public health measures required patients to live there involuntarily. With the increasing powers and duties of the Board of Health, sanitation policy suggested that a clean environment was central to the elimination of disease. However, Isla de Cabras lacked fundamental elements of proper hygiene. Water leaked from the roofs into the patients living quarters. The cistern, as the only supply of water, often failed to provide clean water to the island. The cement floors retained moisture, which made it difficult to keep clean and prevent further infection of the leprosy lesions.

Since the Legislature refused to increase the budget for the leprosarium, the Board of Public Works could not attend to these repairs. The colony was able to conserve funds by reducing the amount spent on clothing, bedding and items of subsistence. In 1907, the Legislature increased the allowance for subsistence from twenty to thirty cents for each leprosy patient per day and, in the following year, provided funding for a new boat but not enough for an experienced boatman to operate the vessel (Puerto Rico, Governor, 1908, p. 306). The hull rapidly eroded, thus suspending the only means of transport from the islet to San Juan. Meanwhile, Mr. Haselbarth, the director of the Board of Charities who reported to the Governor, described Isla de Cabras as a leprosarium that received warm praises from professional visitors and "... courtesies shown by other friends to the unfortunate inmates of the colony" (Puerto Rico, Governor, 1907, p. 190).

In contrast to political administrators who had little involvement with the daily care of the patients, physicians from the Board of Health who provided their medical care, complained about the deplorable condition of the leprosarium at Isla de Cabras. Dr. Quevado Baéz (1904, p. 262), Director of the Board of Health, President of the Puerto Rico Medical Association and physician to the segregated leprosy patients, sympathetically addressed the condition of the leprosarium in his 1904 report to the Association:

Isolation allows for the colony to be more than an asylum that gathers the unfortunate, a cemetery that buries men alive. They are buried without social pity, without the consideration for the sacred respect of individual liberty and without compassion. Facing this terrible bitterness, they remain as a cloud of eternal sadness between the hearth and the hospital. 
For Quevado Baéz (1904, p. 261), the segregation of leprosy patients facilitated observation of uncertain cases, study of the disease, and prevented its spread. However, insufficient governmental appropriations and excessive mistreatment, in Quevado Baéz's opinion, had no scientific or ethical justification.

The disparity between physician and political administrator emerged in 1910 in an inspection of the facilities. The committee from the Governor found there were only 25 leprosy patients at Isla de Cabras from a general population of Puerto Rico at approximately 1,100,000. The board of visitors to the leprosarium anticipated that "its [leprosy's] complete eradication within the next few years is anticipated" (Puerto Rico, Governor, 1909, p. 39). However, there were no simultaneous efforts in the laboratory to develop a treatment in Puerto Rico or import therapies tested in the mainland United States, Hawaii or the Philippines. The opinions of the political officials of the government and the physicians as caregivers contrasted. If the goal of leprosy control in the first decade of the leprosarium was eradication, then the morbid condition of Isla de Cabras and the absence of concomitant scientific research for medical therapy in Puerto Rico show that Isla de Cabras was a living cemetery. Eradication would have only come by using the leprosarium as a repository for death.

The Board of Health and Legislative Assembly eventually reacted to the condition of Isla de Cabras in addressing its excessive isolation. By 1911, the idea of the island isolation for the treatment of leprosy was in question by the Director of Health. The director was concerned that the gloomy geographic isolation of the leper colony conflicted with effective treatment for leprosy. In 1912, the Legislative Assembly created the Institute of Tropical Medicine Hygiene. And, in 1917, they created a new position of Commissioner of Health, who directly advised the Governor. With the increasing development of the health system and research on tropical diseases, leprosy care became more specialized. A hurricane on 22 and 29 August 1916 left the buildings in ruins and 'practically uninhabitable' as described by the Director of the Board of Public Buildings in his memorandum, 'Memoir Repairs to Leper Colony, Goat Island' (Archivo General de Puerto Rico, 1916, Leg. 80). However, there was little discussion among the Governor and his Committees about mending the situation. The search for a new leprosarium was backed by law in 1919, titled Act 76, which required the formation of a Board of the Leper Asylum to monitor the process of creating a new leprosarium. The Legislative Assembly expected that the new leprosarium "[should] not constitute a nuisance" (Archivo General de Puerto Rico, 1919, Leg. 74, Caja 661). Efficiency was essential, and the government would not respond to further requests by the patients. The Legislative Assembly saw the new leprosarium as a final solution to leprosy care, rather than a process of rehabilitation. 
The Governor used the Act to elevate his political image. In response to the issuing of Act 76, the Governor commended his administration, such as Puerto Rico's public health services for controlling the spread of leprosy and the legislators who "always heeded the trend of public opinion" (Puerto Rico, Governor, 1901, p. 361). He disguised the political turmoil that forced his administration to increase services for the leprosy patients through his perfunctory support of leprosy care. In describing the leprosy sufferers as a people who have "obtained great notoriety and greatly attracted the attention of friends and strangers", the Governor displayed his resentment for those constituencies who became advocates for the patients and resisted the many years that the Governor gave no response to the pleas from Isla de Cabras (ibid). Not only did the Directors of Health support the humanity of the leprosy patients, but also did the Protestant congregations. The American Mission for Lepers, a Protestant organization directed by William Danner, rallied for an end to the political inertia of the Puerto Rican Legislature and published in the evangelical journal Puerto Rico Evangélico stating this opinion (American Mission for Lepers, 1919, p. 3). The Protestant Church was a crucial vehicle for the spread of American values through their missionary work in Puerto Rico and their support of the United States' presence there. Therefore, with an increasing awareness of the neglected condition of the leprosy patients, including the passing of a federal law by Congress for the establishment of a National Leprosarium in 1917, the Governor had no choice but to follow the popular opinion to bring some level of relief to the patients. In reality, Act 76 was just a gesture because years passed before the Legislature realized the publicized objective, which was the construction of a new leprosarium.

\section{Trujillo Alto: a new beginning}

New international guidelines in the early 1920s modified the previous model for leprosy control in Puerto Rico. At the Third International Leprosy Congress in 1923, the principle of isolation altered. The Congress still recommended isolation in a hospital, but the option of isolation at home was offered (Bechelli, 1973, p. 287). The change in the language of the guidelines was most dramatic in the recommendations for countries where leprosy was endemic. In these conditions, isolation was to be as humane as possible, but in indigent populations isolation at a hospital or leprosarium was deemed the most efficient and effective method. With a new standard of acceptable and effective treatment for the practice of leprosy control, Puerto Rico was guided by a new model backed by international scientific authorities.

By 1925 the Insular Legislature passed a law that provided the funds for the colony to move from Isla de Cabras to a new site at Trujillo Alto. The site selected was a forty-acre plot situated 22 kilometers from San Juan. The institution fit for sixty patients was spread out over fifteen 
acres and included a three-story administrative building, conference space, a dining room, clinical and surgical wards, and housing facilities. There were eight small houses for the patients, each with four beds and a bathroom.

Strict rules for the release of leprosy patients were passed in anticipation of their move to Trujillo Alto. Since Act 76 allowed patients to remain under domestic isolation, the sanitary laws of 1925 addressed the worry that patients who were actually infected with leprosy would go undetected. Under the Sanitary Regulations of 1925 , a patient was to remain at the colony until he passed bacteriological specifications that indicated he was no longer contagious and a threat to the community ('Sanitary Rules and Regulations', 1925, p. 32).

On 26 June 1926, 43 patients finally moved from the deserted Isla de Cabras to the Leprocomio Insular, or Insular Leper Colony, at Trujillo Alto. The Commissioner of Health, Pedro Ortiz, anticipated that the spacious and verdant landscape of Trujillo Alto "will no doubt improve the moral and physical condition of the inmates" ("A new era for Porto Rico's Leper Colony', 1925, p. 12). However, life within the institution was not as ideal as the legislators and physicians described. Even at Trujillo Alto, the leprosy patients lost their civil rights. Act 76 prohibited their marriage among other patients. Children borne from a leprosy sufferer, if healthy were orphaned to an asylum. Even though the Department of Health presented Trujillo Alto as a new era in the provision of leprosy care, by the 1930s the patients were again left to a neglected position. Rarely did patients have the strength or authority to become their own advocates. Insight into the patient experience in the leprosarium provides a more complete picture of the disparity between public health and political promises and the actuality inside the institution.

\title{
Echoes from within
}

\begin{abstract}
It is very sad this disease that we suffer. Even more bitter are the absurd laws that strip our souls of the love we feel towards our most beloved. Patient, only if you knew the agony of your mother, that you caused her heart to heave from her chest... If you ran to comfort her, upon your return the hospital would punish you. A prison would form, in the flesh, as a prize for your noble effort and only for this crime of leaving, to embrace your dying mother (Joaquín Rívera, 1934, p. 14).
\end{abstract}

Jose Joaquín Rivera, patient at the leprosarium of Trujillo Alto in 1934, documented in his narrative that the laws that segregate and the stigma that results from myths of leprosy's contagiousness are often more wounding to the patient psychologically than the disease itself. There are a number of approaches to assess the psychosocial impact of leprosy on patients. Epidemiological studies provide limited 
descriptions of the leprosy sufferers' identities. Physicians' records, when available, describe the patient's disease, and the medical conclusions. It is only when the patients speak for themselves, that it is possible to have a complete understanding of the significance of living with leprosy.

The patient narrative is often the most difficult to access because traditionally the role of the patient in the doctor-patient relationship has been nominal and not recorded. Social historian, Charles Webster, at a meeting of the British Society for the History of Medicine, criticised historians for constructing the patients of their histories as "merely passive vehicles of particular diseases" (Webster, 1983, p. 40). Building on the clarion calls of George Rosen and his pupil Henry Sigerist, Webster called for historians to resurrect patients from the doldrums of passivity. Indeed there are medical providers who practice an approach to leprosy control that values the participation of leprosy sufferers as central to shaping knowledge on leprosy. Luc Van Parijs (1986, p. 17), who directed the World Health Organization and the International Federation of Anti-Leprosy Associations national leprosy training programmes in the 1980s, stressed that leprosy workers could learn more about leprosy patients and their communities, and thus serve them better, by studying the narratives and case histories that patients provided about their experiences.

A common theme in the narratives of leprosy patients is their sense of social dislocation. Studies from social science indicate that the psychosocial ramifications of leprosy result from the limitations on independence, social isolation, and the loss of status and human dignity of the patient (Wheatley, 1985; Bryant, 1991). Studies on patients living with chronic illness show that, as the disease steadily deforms the body, the image of the former self decays with the formation of a new image of the self as a chronically ill person (Charmaz, 1983, p. 168). With limits on medical knowledge and treatments, patients must rely on themselves to cope with this new identity as persons with leprosy, and rationalize the cause of their illness.

Beyond the disease that causes the leprosy patient to reevaluate his identity and the public health codes that segregate the patient, social stigma isolates the patient even further. Social stigma is thus a significant part of the narrative of leprosy patients, and to understand the influence of leprosy on those who suffered from it and the relationship between the sick, their caregivers, and the mainstream society, it is important to acknowledge those elements in the disease that induce stigma. One important contributor to modern theories on leprosy and stigma is Olaf Kristen Skinsnes (1964, pp. 13-5), M.D., Ph.D., a missionary and leprologist, who said that a negative social response to leprosy was expected based on the way the disease manifests itself in the individual and within the community (see also Gussow, 1989, p. 8). The narratives of the patients who lived in the leprosaria of 
Isla de Cabras and Trujillo Alto support the theories that leprosy is a disease with extensive social repercussions.

Since there are few accounts that describe the leprosy sufferers at Isla de Cabras and Trujillo, epidemiological data can provide general characteristics of the patient community. Dr. P. S. Malaret (1951, p. 35), in his longitudinal study of leprosy in Puerto Rico, noted that before 1 July 1942, no medical records were kept on the patients at the institutions of Isla de Cabras and Trujillo Alto: "as the medical care given these patients up to that time was most rudimentary and, in fact, the institution was considered more in the nature of a place of lodging for those cases which had to be segregated". From the opening of Isla de Cabras to the time of this study in Trujillo Alto in 1942, two-thirds of the community of patients were male and one-third female. While cases varied in age from a five year-old child to a 78 year-old man, most cases were admitted in young adulthood. The majority of men were between the age of 15 and 39 and women, between ten and seventy (ibid, p. 25). As mentioned in the previous chapter, only until the sanitary regulations of 1919 and 1925 could leprosy sufferers remain at home if they met certain required standards of isolation. Therefore, those who were institutionalized were almost all of low-income status and had no other means to care for themselves.

Almost twenty years had passed from when leprosy sufferers first occupied Isla de Cabras and the first appearance of autobiographical records from the patients in the form of letters to the Board of Health and in a regular column in a religious journal, Puerto Rico Evangélico (Maldonado, 1919, p. 17). These publications from the Protestant Evangelical Union of Puerto Rico transformed the muted voices of the community of leprosy patients at Isla de Cabras and Trujillo Alto into an audible narrative on their experiences.

With its first publication on 10 July 1912, the journal PR Evangélico chronicled the ongoing personal and spiritual relationships between the Evangelical congregations and the leprosy patients and the institutional relationships between the government, church and the leprosiarum. The Puerto Rico Evangélico was the governing body and spokesman for the religious life of the Protestant Evangelical churches in Puerto Rico including the Presbyterian, Congregational and Brothers United in Christ (H. U. C., Hermanos Unidos en Cristo) congregations. The publication of PR Evangélico was an outlet to display the religious intensity on the island under American occupation and the spiritual and moral concerns of the leaders and participants of the Evangelical movement. The members of the Evangelical church provided a vital social contact and religious exposure to the leprosy patients at the leprosaria of Puerto Rico, first at Isla de Cabras and later at Trujillo Alto. The Protestant missionaries attended to a number of the leprosy patients at the moment of their death. 
4 'Celebrando el día 4 de Julio en la Isla de Cabra' is a report published in $P R$ Evangélico (1921, ix, 2, p. 15).

${ }^{5}$ Ibid.
Christianity provided the leprosy patients with two identities: a human identity and a community identity. As an outlet for the practice of faith, pursuit of religion enabled patients to search for an omnipotent force that could redeem them in a way that was unobtainable on earth. The Puerto Rico Legislature, the United States government who presided over the politics of Puerto Rico, and the Puerto Rico Board of Health, the forces that determined the earthly fate of the leprosy patients, did not validate these patients as full members of society. However, to the patients, God provided ultimate salvation at their death if they lived observant Christian lives. By practicing Christianity and all the social and religious events this faith entailed, the leprosy patients found an identity and sense of community not only within the leprosarium but within a larger Christian domain.

The earliest accounts of the leprosy patients at Isla de Cabras indicate that patients welcomed visits from the Protestant ministry. The first recorded religious visit to Isla de Cabras was in 1919. Jacinto Maldonado (idem, p. 17), the secretary for the leprosy patients, in a letter to the journal, thanked the Reverend Walter, a Protestant minister from Puerta de Tierra, who visited the colony every third Tuesday of the month. With his preaching on God, Reverend Walter carried a message of love and hope: "Each time this beloved minister comes to this island, we feel completely happy, our hearts are ignited with faith, and hope, and an ardent affection for he who professes to us always." The patients were able to celebrate the United States national day of independence, 4th of July, with clergymen and members of local parishes. In one of the galleries surrounded by a choir singing religious hymns, together the leprosy patients shared in a banquet including ice cream and presents. At the request of bedridden patients, the ministers accompanied them at the bedside. The patients described their lamentations due to leprosy and their separation from society. In response, the religious leaders shared stories of inspiration from the Bible, which provided them sustenance and a faith for a better future. ${ }^{4}$

The Protestant leaders were advocates for the needs of the leprosy sufferers, particularly when the patients were confined to the inhumane asylum of Isla de Cabras and there was no visible response from the Puerto Rican Legislature to ameliorate their condition. Pastors who visited the patients discussed with them their fate on the islet. In the summer of 1920, a column in PR Evangélico described, for the first time, the leprosy patients' concerns in living at Isla de Cabras. After attending the Independence Day celebration, one visitor described the residence at Isla de Cabras as a "cruel torture". ${ }^{5}$ With no natural barrier to mitigate their force, gusts of salty wind penetrated the patients' open sores. Since they had no escape from the inhospitable conditions of the island, the patients were eager for the realization of the plans to construct a new leprosarium. 
${ }^{6}$ Reference to Annual Report of the Governor of Porto Rico (Washington, D.C., 1922, p. 361).

7 'Menos legislacíon y más caridad piden Los lepros' is another report published in $P R$ Evangélico, (1921, ix, $15,3)$.

${ }^{8}$ Reference to the same report cited above.

9 'El mensaje del Gobernador de Puerto Rico a la Legislatura', $P R$ Evangélico, (1921, ix, 17, 4).
In 1919 the Puerto Rico Legislature passed 'Leprosy Act no 76' which formalized the precise nature of the leprosy sufferer's segregation. Through articles in PREvangélico, the leprosy patients pleaded for less legislation and more charity. While the Governor ushered in of a new era science based leprosy care, the patients portrayed an opposing view. ${ }^{6}$ An article published by a member of one of the Protestant parishes compared the Puerto Rican government to the mythical sphinx who annihilated those who could not solve its riddle. ${ }^{7}$ The author asked why the government did not form a committee to search for a new leprosarium site, when the act of 1919 required the relocation of the leprosy sufferers to a new asylum and the patients were in dire need of the move: "Everyone remains lethargic and inactive while these poor inhabitants continue to subsist on this tragic island, isolated, bruised, lacerated, walking of death like infidels abandoned on a barren rock." ${ }^{8}$ This columnist not only alerted the readers to offer their support and solidarity to the leprosy patients, but he chastised the United States federal government for not passing legislation to remove the patients to a more humane site. On behalf of the leprosy sufferers, the Protestant community appealed for greater charity and justice from the Puerto Rican government.

A month after the PR Evangélico attacked the governor for his management of the leprosy patients, the governor responded in an editorial. He reasoned that Puerto Rico was besieged by high illiteracy; the onslaught of diseases such as uncinariasis, malaria, tuberculosis, and what he identified as the most pernicious, syphilis; and a lack of discipline' by the citizens of Puerto Rico. ${ }^{9}$ The governor neglected to indicate the position of leprosy care in his list of challenges, which strongly conveyed the lack of attention leprosy and leprosy patients received by the authorities responsible for making the decisions.

Even though the leprosy patients remained isolated from society when they moved to the new leprosarium in Trujillo Alto, they experienced a revitalized sense of identity. One of the ways that the leprosy patients built their own sense of humanity was with their establishment of a religious society at Trujillo Alto. There was a network of these evangelical groups throughout Puerto Rico as a form of outreach by the Protestant congregations. The inauguration of such a society at the leprosarium at Trujillo Alto on 16 May 1928, validated the existence of the leprosy community as a religious community and situated Trujillo Alto within the network of Protestant communities on the island. Living in a society who had rejected them, the leprosy patients found a social organization and opportunity for leadership in the religious organization. Each year the leprosy patients elected their community a president, vice-president, secretary, and treasurer to govern the society. The mission of the society was to develop the mind and spirit of the patients through prayer. The organizers fulfilled this purpose by coordinating religious services in the leprosarium and attracting a regular program of social events. Dr. Pedro Ortíz, 
Commissioner of Health, delivered the inaugural address for the 'Monday socials', an event that brought prominent intellectuals of Puerto Rico to meet with the patients (Maldonado, 1929, p. 12). A number of the conferences targeted the issue of leprosy and stigma directly. An administrator from the Insular Mental Asylum of Puerto Rico lectured to the patients on the importance of optimism (Tembleg and Maldonado, 1933 , p. 12). Since the patients by law were confined to the leprosarium, the religious society of the Leprosarium attempted to bring the world to Trujillo Alto.

The patient narratives are a source to evaluate the social implications of leprosy. It is tragic that at the moment of their death, the most is known about the leprosy patients through their obituaries. Articles describe the patients' immediate display of joy and gratitude upon the arrival of their spiritual caregivers and the despair upon their departure. The visitors brought a sense of humanity to the patients through simple means, such as in the form of books, ice cream, lectures, patriotism, and religious hope. In their appreciation of these basic elements of a human identity, the patients became like children, reliant on their caregivers and the words of the Bible that sustained them until their ultimate redemption at death. Indeed, the Protestant missions also benefited as caregivers for and protectors of the leprosy patients: they spread the word of God; they raised funds, both on the mainland and in Puerto Rico under the aegis of leprosy care; and they acted as a vehicle for the dissemination of American values and traditions in the early years of the United States colony.

\section{Conclusion}

By relying on unique primary source material from Puerto Rico, from government records, medical journals, patient narratives, and personal correspondences, this study of leprosy from 1898 to the 1930s in Puerto Rico attempts to show the complex interacting factors that create a history of disease. Indeed, leprosy is a disease distinct from other chronic, infectious ailments. The loss of functional limbs, the negation of facial features, and the ulceration of the skin have wider ramifications than the physical transformation of the sufferer's body. Particularly when untreated, the visual horror that leprosy can induce often results in the exclusion of the leprosy sufferer from society. The isolation of leprosy patients into colonies, called leprosaria, shattered patients' own notions of humanity while fracturing their connection to their families and the larger society.

The characterization of a disease as a biological entity is critical for its control, because until a disease is perceived, named, and then responded to, it lacks credibility as a valid ailment (Rosenberg, 1992, p. xiii). In the case of leprosy, the prevailing medical knowledge failed to structure a biological framework for understanding the disease. 
The gaps in scientific knowledge of leprosy in the nineteenth century left unanswered questions on how governments and communities should control leprosy.

At a local level, even without a concrete understanding of the pathogenesis of leprosy, public health authorities went beyond the traditional practice of quarantine for contagious diseases to control the spread of leprosy. Quarantine in the nineteenth and early twentieth century was a common method of controlling the spread of contagious diseases like smallpox, syphilis, yellow fever, cholera, bubonic plague, tuberculosis, and diphtheria. It was often exercised as a means to prevent the spread of disease through international maritime trade. However, leprosy isolation was often involuntary and indefinite. Since there was no cure available for leprosy and death was the eventual prognosis, segregation provided an efficient means for public health authorities to control leprosy.

It is unfortunate that there are few records that document life inside the leprosarium because, when the patients speak in their own voice, it is possible to see the way in which leprosy transformed the meaning of their identities. Those records that exist show individuals severed from familial ties and imbued with shame as exiles. The patients exposed their unyielding spiritual faith through narratives. Their human connection to society was through religious organizations like the Protestant Evangelical Union. In the patients' greatest despair and loss of humanity, there is woven a story of charity, commitment to those less fortunate and a religious thread that united both sufferer and spiritual caregiver.

The patient narratives also reveal the extent to which the leprosy patients were captive to the messages of the religious organizations. The Protestant Union organized religious events with Bible readings and lectures around traditional American celebrations such as 4th of July, Mother's Day, New Year's, Christmas. At these events, visitors from other congregations brought the patients flowers, candies and books. Like children tearfully departing parents, the patients stood on the rocks of Isla de Cabras with their scarves and carnations in hand, saluting their visitors as they departed into the Bay of San Juan (Rodríguez Vera, 1920, p. 15). There was no reason for the patients to resist the inundation of American culture because the Puerto Rican community had rejected them and banished them into seclusion. The Protestant Union recognized the leprosy sufferers as humans.

Rev. Rodríguez Vera, pastor to the leprosy sufferers at Isla de Cabras, requested, in the narrative at the beginning of this paper, that in the leprosy sufferers' invisibility, society not nullify their existence; that in their isolation, society offer their solidarity, and that when they were no longer living, that society preserve a memory. Tragically, the voices of leprosy patients in Puerto Rico have gone unrecorded in a history that links the social importance of their existence as 
humans, within a larger social history of public health, science, and medicine. This history of leprosy in Puerto Rico from 1898 to the 1930 's serves to record and honor those patients' lives and proposes a model for the social history of leprosy and public health that represents the significance of these historical events to the people that lived them.

\section{BIBLIOGRAPHIC REFERENCES}

News Review

29 Nov.-12 Dec. 1973

Puerto Rico Health Review 1925

Almodóvar, P. I., Figueroa, J.

1990

American Bible Society 1989

American Mission for Lepers

1921

Anderson, Warwick 1998

Annual Report of the Military Governor of

Porto Rico

1922

Annual Report of the Military Governor of Porto Rico

1909

Annual Report of the Military Governor of Porto Rico

1908

Annual Report of the Military Governor of Porto Rico

1907

Annual Report of the Military Governor of Porto Rico

1902

Archivo General de Puerto Rico, San Juan 1893-1950

Arnold, David

1988
'2400 Puerto Ricans are suffering a form of death in life.

San Juan, pp. 34-38.

'A new era for Porto Rico's Leper Colony',

$1: 5$, p. 12 .

'Leprosy in Puerto Rico: a decade later'.

Boletín de la Asociación Medica de Puerto Rico, 82:10, pp. 466-8.

'Leviticus'. The Holy Bible: New Revised Standard Version.

New York, American Bible Society, p. xiii.

'Menos legislación y más caridad piden los lepros'.

Puerto Rico Evangélico, ix:15, p. 3.

'Where is the postcolonial history of medicine?'.

Bulletin of the History of Medicine, 72, pp. 522-30.

Washington, D.C.,

Government Printing Press.

Washington, D.C.

Government Printing Press.

Washington, D.C.,

Government Printing Press.

Washington, D.C.,

Government Printing Press.

Washington, D.C.,

Government Printing Press.

Fondo Obras Públicas,

Serie Edificios Públicos

'Imperial medicine'. In M. J. Lewis and R. MacLeod (eds.),

Disease, medicine, and empire. London, Routledge, pp. 1-21. 
Bechelli, L. M.

1973

Botet Vázquez, M., Sanchez, J. L. and

Ramos Caro, F. 1981

Bryant, J. S. 1991

Charmaz, K. 1983

'Advances in leprosy control in the last 100 years'.

International Journal of Leprosy and Other Mycrobacterial Diseases, 41: 3, p. 287.

'Incidence of leprosy in Puerto Rico, update 1980'.

Boletín de la Asociación Medica de Puerto Rico, 73, pp. 488-96.

An anthropological study of the stigma of leprosy. M. A. thesis, Berkeley, California State University.

'Loss of self: a fundamental form of suffering in the chronically ill', Sociology of Health and Illness, 5: 2, p. 168.

Doull, J. A.; Martínez, E., 'A note on leprosy in Puerto Rico'.

et al..

Boletín de la Asociación Medica de Puerto Rico, 33: 6, pp. 217-23.

1941

Farley, John

1991

Gussow, Zachary 1989

Hostos, Adolfo de 1966

Iliffe, John 1987

Joaquín Rívera, J. 1934

Malaret, P. J. 1951

Maldonado, Jacinto 1929

Maldonado, Jacinto 1919

Marine Hospital Service Oct. 6, 1899

Puerto Rico, Governor 1901

Quevado Báez, M. 1904

'Restaurarán ruinas

Leprocomio de

Palo Seco' Sept. 1964

Rodríguez Vera, A. 1920

Rosenberg, C. 1992

Sanchez, F. and Almodóvar, $\mathrm{P}$.

1925

Bilharzia: a bistory of imperial tropical medicine. Cambridge, Cambridge University.

Leprosy, racism, and public health: social policy in chronic disease control. Boulder, Westview Press.

Historia de San Juan, ciudad murada. San Juan, Instituto de Cultura Puertorriqueña.

The African Poor.

Cambridge, Cambridge University.

'Desaparecerá la Sociedad de Esfuerzo Cristiano del Leprocomio?'. Puerto Rico Evangélico, xxii:13, p. 14.

'Leprosy in Puerto Rico'.

Boletín de la Asociación Medica de Puerto Rico, 43, pp. 1-64.

'Los Lunes Sociales del Esfuerzo Cristiano del Leprocomio'.

PR Evangélico, xvii, 42, p. 12.

'Desde Isla de Cabras', PR Evangélico, vii, 21.

Public Health Reports.

Washington D.C., United States Marine Hospital Service, p. xiv.

'Report of the Director of Sanitation'. Annual Report of the Governor of Porto Rico. Washington, D.C., Government Printing Press.

'Juicios acerca del aislamiento y contagiosidad de la lepra'.

Boletín de la Asociación Medica de Puerto Rico, ii: 17.

El Reportero.

San Juan, p. S-6, 14

'Los lazarinos están poseídos de una fe inquebrantable en los anunciados propositos del Comsionado del Interior Señor Esteves, de construir en primer término el sanatorio para ellos'. PR Evangélico, ix, 2, p. 15.

'Framing disease: illness, society, and history'. In C. Rosenberg and J. Golden (eds.), Framing disease: studies in cultural bistory. New Brunswick.

'Leprosy in Puerto Rico: update 1994' (permission from author), pp. 1-14, (printing forthcoming).

'Sanitary Rules and Regulations for the Release of Lepers'. Puerto Rico Health Review. 1:4. p. 32. 
BEYOND QUARANTINE

Skinsnes, O. 'Leprosy in society, I'.

1964 Leprosy Review, 35, 1.

Tembleg, R. and

Maldonado, J.

'Notas del Esfuerzo Cristiano E. A. Ruiz del Leprocomio'.

PR Evangélico, xxii, 1.

1933

United States Public

Health Service

1904

Annual Report of the Surgeon-General of the Public Health and

Marine Hospital Service of the United States. Washington, D.C.,

Government Printing Press, p. 115.

Van Parijs, Luc G.

1986

Health education in leprosy work: a manual for health workers.

London.

Vázquez Ortiz, A.

1992

La institución del lazareto en el siglo XIX: historia de su establecimiento en isla de cabras. M.A. thesis, San Juan, Centro de Estudios Avanzados de Puerto Rico y el Caribe.

Vera, A. Rodríguez

1920

'Los lazarinos están poseídos de una fe inquebrantable en los anunciados propósitos del Comisionado del Interior Señor Esteves, de construir en primer término el sanatorio para ellos'. PR Evangélico, ix: 2, p. 15.

Webster, Charles

1983

'The historiography of medicine'. In P. Corsi and P.J. Weindling (eds.),

Information sources in the bistory of science and medicine.

London, Butterworth Scientific, p. 40.

Wheatley, M.A.

Leprosy: a disease apart, a historical and cross-cultural analysis of stigma.

1985

Doctoral Dissertation, Ottawa, Carleton University.

Submitted on May 2003.

Approved on June 2003. 